\title{
HUBUNGAN PELAKSANAAN TIMBANG TERIMA DENGAN KESELAMATAN PASIEN DI RUANG RAWAT INAP KELAS III RSI SULTAN AGUNG SEMARANG
}

\author{
Windyastuti $^{1}$, Gilang Deka Hayuna ${ }^{2}$, Rahayu Winarti ${ }^{3}$ \\ 1. Program Studi Ners STIKES Widya Husada Semarang \\ 2. Program Studi Ners STIKES Widya Husada Semarang \\ 3. Program Studi Ners STIKES Widya Husada Semarang \\ E-mail: fengmi.windy85@gmail.com
}

\begin{abstract}
Abstrak
Latar Belakang : Timbang terima adalah transfer tentang informasi yang mencakup peluang pertanyaan, klasifikasi, konfirmasi tentang pasien, tanggung jawab utama dan kewenangan perawat dari perawat sebelumnya ke perawat yang akan melanjutkan perawatan. Komunikasi dalam timbang terima memiliki peranan penting dalam penyampaian berbagai informasi pasien yang seharusnya dilaksanakan sesuai dengan SPO yang berlaku pada setiap pergantian shift, karena SPO tersebut dapat menunjang tidak terjadi salah persepsi ataupun ketidaksinambungan informasi, sehingga tidak terjadi kesalahan tindakan atau melalaikan suatu tindakan yang akan dapat beresiko terhadap keselamatan pasien. Tujuan: Mengetahui hubungan pelaksanaan timbang terima dengan keselamatan pasien di ruang rawat inap kelas III RSI Sultan Agung Semarang. Metode : Jenis penelitian yaitu analitik korelasi dengan pendekatan cross sectional. Pengambilan sampel dengan tekhnik Porpotionate Sampling. Data dikumpulkan melalui kuesioner, dianalisis menggunakan uji statistik Spearman Rank dengan batas kemaknaan $\alpha=5 \%$ (0.05). Hasil : Terdapat 52\% pelaksanaan timbang terima baik dan 38,8\% keselamatan pasien baik dengan hasil uji statistik nilai $\rho$ value $=0,000<0,05$ dan $r=0,722$. Kesimpulan : Hasil penelitian menunjukan bahwa ada hubungan pelaksanaan timbang terima dengan keselamatan pasien
\end{abstract}

Kata Kunci : Keselamatan Pasien, Timbang Terima, pelaksanaan

\section{RELATIONSHIP OF IMPLEMENTATION HANDOVER WITH SAFETY PATIENTS IN CLASS III INPATIENT ROOM, RSI SULTAN AGUNG SEMARANG}

\begin{abstract}
Background : Communication in handover has an important role in submission of various patient information that should be carried out in accordance with the SPO that applies at each take over shifts, because the SPO can support the absence of misperception or discontinuity of information,so there is no wrong action or neglect an action that will be risky to patient safety. The specific objectives of this research are: Analyzing the relationship of Handover with Patient Safety in Inpatient Class III RSI Sultan Agung Semarang. Methods :This type of research is analytic correlation with cross sectional approach. Sampling with Porpotionate Sampling technique. Data was collected through questionnaires, analyzed using Spearman Rank statistical tests with a significance limit of $\alpha=5 \%$ (0.05). Result : There were 52\% of the implementation of the handover well and $38.8 \%$ of the patient's safety both with the results of the statistical test the value of $\rho$ value $=0,000<0,05$ and $r=0,722$

Conclution : The results of the study indicate that there is a relationship between implementation and acceptability of patient safety
\end{abstract}

Keywords: Patient Safety, take-over shift, implementation 


\section{Pendahuluan}

Berdasarkan World Health Organization keselamatan pasien merupakan prinsip dasar dalam perawatan kesehatan (Depkes RI, 2011). Permenkes nomor 11 tahun 2017 juga mengatur tentang keselamatan pasien sebagai suatu sistem yang membuat pasien lebih aman, dengan tindakan untuk meminimalkan terjadinya resiko serta pencegahan terjadinya cedera yang disebabkan oleh kesalahan akibat pelaksanaan tindakan atau seharusnya melakukan tindakan, namun tidak dilakukan. WHO National Patient Safety Agency melaporkan dalam rentang waktu 1 tahun pada tahun 2016 angka kejadian keselamatan pasien dari negara Inggris sebanyak 1.879.822 kejadian. Ministry of Health Malaysia 2013 melaporkan angka kejadian keselamatan pasien dalam 1 tahun sebanyak 2.769 kejadian (WHO, 2017). Di Indonesia sendiri jumlah IKP ini setiap tahun terus meningkat diantaranya pada tahun 2008 terdapat 61 kasus selang 1 tahun berikutnya pada tahun 2009 terdapat 114 kasus, sedangkan untuk tahun 2010 sebanyak 103 kasus, dan pada tahun 2011 periode bulan Januari- April terdapat sebanyak 34 kasus (KKPRS, 2012)

Komunikasi merupakan bagian fundamental antar profesi kesehatan dalam penyampaian dan penerima informasi mengenai perkembangan kondisi pasien (Suhriana, 2012). Jurnal penelitian Uyan Ari Lidiyah menyatakan bahwa perlu adanya peningkatan pengetahuan komunikasi (perawat, dokter, dan departemen penunjang medis yang lain), pelatihan kesalamatan pasien untuk mengurangi insiden keselamatan pasien (Qomariah dan Uyan, 2015). Bentuk komunikasi antar perawat terutama dalam pelaksanaan asuhan keperawatan meliputi timbang terima pasien (Sugiharto dkk, 2012).

Pelaksanaan timbang terima menurut penelitian Andi Prayitno menyatakan bahwa untuk menghindari penyimpangan komunikasi saat timbang terima perawat perlu memenuhi syaratyaitu dapat dipercaya pesan jelas, isi jelas dan berkesinambunga. Hasilnya menunjukan tahap persiapan timbang terima dalam kategori kurang (11,06\%), tahap pelaksanaan kategori cukup $(62,61 \%)$ dan tahap post timbang terima kategori kurang $(1,76 \%)$, sedangkan secara keseluruhan timbang terima di RS tersebut berkategori baik (40,0\%) dan kategori cukup (60,0\%) (Prayitno, 2017).

Timbang terima harus dilakukan seefektif mungkin dengan penjelasan yang jelas, akurat, dan lengkap untuk menunjang keberlangsungan asuhan keperawatan dapat berjalan dengan baik. 
Informasi dalam pemberian pelayanan kesehatan pun berkesinambungan tidak terjadi salah presepsi yang dapat berujung kesalahan dan menimbulkan kerugian pada pasien (Nursalam, 2016). Hal ini didukung dengan penelitian Triwibowo yang menyimpulkan bahwa untuk pelaksanaan Handover/ timbang terima dapat berjalan dengan baik serta keselamatan pasien terlindungi diperlukan adanya pelatiahan timbang terima, supervisi tiap ruangan, tanggung jawab, kerjasama, motivasi komunikasi, pelaporan yang adekuat serta mengubah budaya dari Blaming cultur menjadi Safety cultur (Manopo dkk, 2013; Triwibow, 2015).

Berdasarkan wawancara dan observasi tentang timbang terima di Ruang Baitul Izzah 1 dan 2 dengan 5 orang perawat menyampaikan bahwa timbang terima tidak sering dibuka oleh kepala ruang, ada yang datang terlambat, intervensi masih ada yang terlewati, tindakan yang sudah dan belum tidak disampaikan secara lengkap pada perawat jaga selanjutnya, timbang terima tidak dipimpin oleh kepala ruang, 2 orang perawat tidak mengikuti timbang terima dari awal karena datang terlambat, bahkan 1 perawat ada yang sambil melaksanakan tindakan lain ke pasien, sehingga menghambat timbang terima karena pencatatan timbang terima tidak lengkap sehingga harus menanyakan ke perawat yang bersangkutan, tindakan yang sudah dilakukan tidak disampaikan dengan lengkap.

\section{Tinjauan Teoritis}

\section{A. Keselamatan Pasien}

Keselamatan pasien adalah suatu sistem dimana Rumah Sakit membuat asuhan perawatan lebih aman yang meliputi assesment resiko, identifikasi dan pengelolaan hal yang berhubungan dengan resiko pasien, pelaporan dan analisis insiden, kemampuan belajar dari insiden dan tindak lanjutnya serta implementasi solusi untuk meminimalkan timbulnya resiko dan mencegah terjadinya resiko yang disebabkan oleh kesalahan (Priyoto dan Mega, 2017).

\section{Tujuh Langkah Menuju Keselamatan Pasien}

Menurut KKPRS 2008 Tujuh langkah menuju keselamatan pasien bagi staf rumah sakit dilakukan dengan tujuh cara meliputi :

a. Membangun kesadaran akan nilai keselamatan pasien dengan membuat kebijakan rumah sakit terkait peran dan tanggung jawab individu bila terjadi insiden 
b. Membangun komitmen yang kuat tentang keselamatan pasien dengan memasukan keselamatan pasien dengan memasukan keselamatan pasien sebagai agenda kerja dan program pelatihan staf

c. Mengembangkan sistem dan proses pengelolaan resiko dengan menetapkan indikator kinerja bagi sistem pengelolaan resiko dan penilaian resiko

d. Mengembangkan sistem pelaporan insiden

e. Mengembangkan cara berkomunikasi dengan pasien bila terjadi insiden

f. Mengembangkan sistem analisis terhadap akar penyebab masalah

g. Mengimplementasikan sistem keselamatan pasien yang sudah dibuat (Triwibowo, 2013).

\section{B. Timbang Terima}

\section{Pengertian}

Timbang terima memiliki beberapa istilah lain yaitu handover, overhand, report nursing, operan, dan serah terima. Timbang terima merupakan suatu cara dalam menyampaikan dan menerima sesuatu (laporan) yang berkaitan dengan keadaan pasien. Timbang terima merupakan komunikasi yang terjadi pada saat perawat melakukan pergantian shift dan memiliki tujuan yang spesifik yaitu mengkomunikasikan informasi tentang keadaan pasien pada asuhan keperawatan sebelumnya (Triwibowo, 2013)

\section{Metode dalam Timbang Terima}

Metode dalam timbang terima terbagi menjadi 2 yaitu :

a. Timbang terima dengan metode tradisional

1) Dilakukan hanya di meja perawat

2) Menggunakan satu arah komunikasi sehingga tidak memungkinkan munculnya pertanyaan atau diskusi

3) Ada pengecekan ke pasien hanya sekedar memastikan kondisi secara umum

4) Tidak ada kontribusi atau feedback dari pasien dan keluarga, sehingga proses informasi dibutuhkan oleh pasien terkait status kesehatannya tidak up to date

b. Timbang terima dengan metose bedside handover

Timbang terima yang dilakukan disamping tempat tidur pasien atau keluarga pasien secara langsung untuk mendapatkan feedback

Menurut Putra (2017) Metode pelaksanaan timbang terima diantaranya : 
1) Menggunakan tape recorder

2) Menggunakan komunikasi oral atau spoken

3) Menggunakan komunikasi tertulis- written

\section{Metode Penelitian}

Penelitian dilakukan di ruang rawat inap kelas III RSI Sultan Agung Semarang menggunakan metode analitik korelasi dimana suatu penelitian yang dilakukan untuk mengetahui hubungan atau korelasi dua variabel yang diteliti, pendekatan yang dipakai cross sectional. Sampel yang digunakan menggunakan rumus slovin dengan mengantisipasi adanya drop out maka ditambah 10\% dari sampel sehingga jumlah sampel menjadi 98 perawat. Teknik pengambilan sampel pada penelitian ini menggunakan Proportionate Sampling, total sampel 98 perawat. Kuesioner merupakan instrumen yang digunakan dalam penelitian yaitu variabel pelaksanaan timbang terima terdiri dari 36 pernyataan dan variabel keselamatan pasien 26 pernyataan.

\section{Hasil Penelitian}

\section{A. Karakteristik Responden}

Tabel 1

Karakteristik Responden Berdasarkan Umur, Lama Kerja, Jenis Kelamin dan Tingkat Pendidikan Perawat di Ruang Rawat Inap Kelas III RSI Sultan Agung Semarang Bulan Juli 2018

\begin{tabular}{|c|c|c|}
\hline Karakteristik & Frekuensi & Presentase $(\%)$ \\
\hline $\begin{array}{l}\text { Umur } \\
21-30 \text { tahun } \\
31-40 \text { tahun }\end{array}$ & $\begin{array}{l}76 \\
22\end{array}$ & $\begin{array}{l}77,6 \\
22,4\end{array}$ \\
\hline Total & 98 & 100 \\
\hline $\begin{array}{l}\text { Lama Kerja } \\
<5 \text { tahun } \\
>5 \text { tahun }\end{array}$ & $\begin{array}{l}51 \\
47\end{array}$ & $\begin{array}{l}52,0 \\
48,0\end{array}$ \\
\hline Total & 98 & 100 \\
\hline $\begin{array}{l}\text { Jenis Kelamin } \\
\text { Laki-laki } \\
\text { Perempuan }\end{array}$ & $\begin{array}{l}24 \\
74\end{array}$ & $\begin{array}{l}24,5 \\
75,5\end{array}$ \\
\hline Total & 98 & 100 \\
\hline $\begin{array}{l}\text { Tingkat Pendidikan } \\
\text { DIII Keperawatan } \\
\text { SI Keperawatan } \\
\text { Profesi Ners } \\
\text { S2 Keperawatan }\end{array}$ & $\begin{array}{c}66 \\
11 \\
21 \\
0\end{array}$ & $\begin{array}{c}67,3 \\
11,2 \\
21,4 \\
0\end{array}$ \\
\hline Total & 98 & 100 \\
\hline
\end{tabular}




\section{B. Analisis Univariat}

\section{Pelaksanaan Timbang Terima}

Tabel 2

Distribusi Frekuensi Responden Berdasarkan Gambaran Pelaksanaan Timbang Terima di Ruang Rawat Inap Kelas III RSI Sultan Agung Semarang Bulan Juli 2018

$$
(\mathbf{n}=98)
$$

\begin{tabular}{ccc}
\hline $\begin{array}{c}\text { Pelaksanaan Timbang } \\
\text { Terima }\end{array}$ & Frekuensi & Presentase (\%) \\
\hline Baik & 51 & 52 \\
Cukup Baik & 47 & 48 \\
Kurang Baik & 0 & 0 \\
\hline Total & 98 & 100 \\
\hline
\end{tabular}

\section{Keselamatan Pasien}

Tabel 3

Distribusi Frekuensi Responden Berdasarkan Gambaran Keselamatan Pasien di Ruang Rawat Inap Kelas III RSI Sultan Agung Semarang Bulan Juli 2018

$$
(\mathbf{n}=98)
$$

\begin{tabular}{ccc}
\hline Keselamatan Pasien & Frekuensi & Presentase (\%) \\
\hline Baik & 38 & 38,8 \\
Cukup Baik & 60 & 61,2 \\
Kurang Baik & 0 & 0 \\
\hline Total & 98 & 100 \\
\hline
\end{tabular}

\section{Analisis Bivariat}

Tabel 4

Hubungan Pelaksanaan Timbang Terima dengan Keselamatan Pasien di Ruang Rawat Inap Kelas III RSI Sultan Agung Semarang Bulan Juli 2018

\begin{tabular}{|c|c|c|c|c|c|c|c|c|c|c|}
\hline \multirow{3}{*}{$\begin{array}{c}\text { Pelaksanaan } \\
\text { Timbang } \\
\text { Terima }\end{array}$} & \multicolumn{6}{|c|}{ Keselamatan Pasien } & \multirow{2}{*}{\multicolumn{2}{|c|}{ Total }} & \multirow{3}{*}{$\boldsymbol{r}$} & \multirow{3}{*}{$\rho$ value } \\
\hline & \multicolumn{2}{|c|}{ Baik } & \multicolumn{2}{|c|}{ Cukup Baik } & \multicolumn{2}{|c|}{$\begin{array}{c}\text { Kurang } \\
\text { Baik }\end{array}$} & & & & \\
\hline & $\mathbf{n}$ & $\%$ & $\mathbf{n}$ & $\%$ & $\mathbf{n}$ & $\%$ & $\mathbf{n}$ & $\%$ & & \\
\hline Baik & 37 & $37,8 \%$ & 14 & $14,3 \%$ & 0 & $0 \%$ & 51 & $52,0 \%$ & & \\
\hline Cukup Baik & 1 & $1,0 \%$ & 46 & $46,9 \%$ & 0 & $0 \%$ & 47 & $48,0 \%$ & 0,722 & 0,000 \\
\hline Kurang Baik & 0 & $0 \%$ & 0 & $0 \%$ & 0 & $0 \%$ & 0 & $0 \%$ & & \\
\hline Total & 38 & $38,8 \%$ & 58 & $61,2 \%$ & 0 & $0 \%$ & 98 & $100 \%$ & & \\
\hline
\end{tabular}

$$
(\mathbf{n}=98)
$$

\section{Pembahasan}

\section{A. Karakteristik Responden}

Tabel 1 menunjukan bahwa responden dengan umur 21-30 tahun sebanyak 76 orang $(77,6 \%)$, umur $32-40$ tahun sebanyak 22 orang $(22,4 \%)$. Teori menurut Notoatmodjo 
(2012) menyatakan semakin cukup umur, tingkat kematangan dan kekuatan seseorang akan lebih matang dalam berfikir dan bekerja. Teori Potter \& Perry (2010) juga menyatakan bahwa kemampuan berfikir kritis meningkat secara teratur selama usia dewasa. Penelitian Handayani (2017) juga menyatakan bahwa semakin muda usia perawat memiliki kecenderungan menimbulkan terjadinya insiden keselamatan pasien dengan usia perawat yang lebih tua. Dari hasil penelitian diatas menunjukan tidak berarti semakin bertambah umur semakin berkurang produktifitas kerja.

Lama kerja responden pada penelitian ini $<5$ tahun ada 51 orang $(52 \%)$ dan $>5$ tahun 47 orang (48\%). Semakin banyak lama kerja perawat maka semakin banyak pengalaman perawat dalam memberikan asuhan keperawatan yang sesuai dengan standar atau prosedur tetap yang berlaku (Nursalam, 2011). Penelitian Manorek dkk (2017) menyatakan hal yang sama bahwa semakin lama seseorang bekerja, tingkat kematangannya dalam menghadapi berbagai situasi ditempat kerja akan lebih tinggi sehingga ia dapat mengelola dengan lebih baik. Penelitian mengenai lama kerja dengan keselamatan pasien juga telah dilakukan Astriana (2014) bahwa ada hubungan lama kerja dengan kinerja perawat dalam program keselamatan pasien ( $\rho$ value $=0,033$ ).

Sebagian besar responden pada penelitian ini adalah perempuan yaitu 74 orang $(75,5 \%)$. Hal ini sesuai dengan filosofi mother instinct bahwa mayoritas perawat datang dari kaum perempuan, dimana seorang perempuan memiliki naluri merawat diri sendiri sebagaimana tercermin pada seorang ibu serta naluri yang sederhana dalam memelihara kesehatan keluarganya dan anak-anaknya (Kozier et all, 2010). Hal tersebut berlawanan dengan Robbins (2008) yang menyatakan sebenarnya tidak terdapat perbedaan yang konsisten antara pria dan wanita dalam hal kemampuan memecahkan masalah, menganalisis, dorongan kompetitif, motivasi, sosiabilitas atau kemampuan belajar. Penelitian Handayani (2014) menunjukan kepatuhan terhadap penerapan keselamatan pasien sebanyak $22,8 \%$ perempuan dan laki-laki $40 \%$.

Tingkat pendidikan dapat meningkatkan pengetahuan perawat untuk dapat menerapkan pedoman keselamatan pasien, sehingga dapat menurunkan angka kejadian yang tidak diharapkan (Hughes 2008 dalam Fadriyanti dan Yosi 2018). Menurut hasil wawancara dengan perawat menyatakan bahwa di RSI Sultan Agung Semarang rutin melaksanakan 
pelatihan keselamatan pasien untuk meningkatkan pengetahuan perawat DIII, SI, maupun Profesi Ners pada setiap ruang dan dilaksanakan setahun sekali.

\section{B. Pelaksanaan Timbang Terima}

Berdasarkan tabel 2 menunjukan bahwa dari 98 responden yaitu pelaksanaan timbang terima baik sebanyak 51 orang (52\%) dan cukup baik sebanyak 47 orang (48\%). Berdasarkan Australian Resource Centre for Healthcare Innovation (2009) dalam Triwibowo (2013) terdapat enam standar prinsip timbang terima adalah kepemimpinan, pemahaman, peserta yang mengikuti, waktu, tempat, dan proses timbang terima.

\section{Keselamatan Pasien}

Berdasarkan tabel 3 menunjukan bahwa dari 98 responden yaitu keselamatan pasien baik sebanyak $38(38,8 \%)$ dan cukup baik sebanyak 60 orang $(61,2 \%)$. Keselamatan pasien berisi enam Sasaran Keselamatan Pasien (SKP). Prosedur keselamatan pasien ini sangat menjamin penjaminan mutu dari rumah sakit, karena itu rumah sakit dapat dikatakan baik jika pelayanan untuk keselamatan pasien juga sudah baik (Lestari, 2012). Persepsi untuk melindungi pasien dari kesalahan tata laksana maupun cidera akibat intervensi meliputi kumpulan norma, standar profesi, kebijakan, komunikasi dan tanggungjawab dalam keselamatan pasien (Rosyada, 2014)

\section{Hubungan Pelaksanaan Timbang Terima dengan Keselamatan Pasien}

Terdapat hubungan pelaksanaan timbang terima dengan keselamatan pasien di ruang rawat inap kelas III RSI Sultan Agung Semarang dengan nilai $r$ sebesar 0,722 yang menunjukan pada rentang 0,60-0,799 maka menurut Sugiyono (2011) nilai kriteria korelasi tersebut kuat artinya hubungan pelaksanaan timbang terima dengan keselamatan pasien merupakan hubungan yang kuat. Nilai positif pada kofisien nilai $r$ juga menandakan hubungan searah sehingga semakin baik pelaksanaan timbang terima maka semakin baik pula keselamatan pasien. Menurut Permenkes (2011) menyatakan bahwa komunikasi timbang terima yang tidak dilakukan dengan benar dapat mengakibatkan berbagai masakah diantaranya keterlambatan dalam diagnosa medis dan peningkatan kemungkinan efek samping, juga konsekuensi lain termasuk biaya yang lebih tinggi perawatan kesehatan penyedia yang lebih besar dan ketidakpuasan pasien. Hal ini juga sesuai dengan penelitian Kamil (2011) timbang terima yang tidak efektif dapat berkonstribusi terhadap kesalahan dan pelanggaran dalam keselamatan perawatan pasien, termasuk kesalahan pengobatan, salah operasi dan kematian pasien. Penelitian ini sejalan dengan penelitian yang berjudul "Handover sebagai 
upaya peningkatan keselamatan pasien (patient safety) di Rumah Sakit bahwa terdapat hubungan antara handover atau timbang terima dengan patient safety (keselamatan pasien) dengan hasil $(53,2 \%)$ responden menyatakan timbang terima baik dan $(51,6 \%)$ keselamatan pasien baik dengan nilai $\rho$ value 0,04. Penelitian lain juga menunjukan peningkatan bermakna terhadap pelaksanaan timbang terima pasien dan penerapan keselamatan pasien sesudah perawat pelaksana diberikan pelatihan timbang terima ( $\rho$ value $: 0,000, \alpha: 0,05)$

\section{Kesimpulan}

Pelaksanaan timbang terima di Ruang Rawat Inap Kelas III RSI Sultan Agung Semarang yaitu baik (52\%) dan cukup baik (48\%). Keselamatan pasien di Ruang Rawat Inap Kelas III RSI Sultan Agung Semarang yaitu baik (38,8\%) dan cukup baik (61,2\%). Ada hubungan antara pelaksanaan timbang terima dengan keselamatan pasien di ruang rawat inap kelas III RSI Sultan Agung Semarang ( $\rho$ value $=0,000)$ dengan arah hubungan positif, kekuatan hubungan yang kuat, dan arah korelasi yang searah

\section{Saran}

Rumah sakit memerlukan evaluasi pelaksanaan timbang terima sesuai dengan Standar Prosedur Operasional (SPO) untuk mencegah ketidaksinambungan transfer informasi yang berdampak pada keselamatan pasien

\section{Daftar Pustaka}

Andayani, N.M.D. 2017. Hubungan Karakteristik dan Persepsi Perawat. Tentang Sasaran Keselamatan Pasien dengan Persepsi Timbang Terima di Ruang Oleg RSUD Bandung. [Skripsi]. Bali (ID): Universitas Udayana

Astriana, Noor N.B, Andi I.S. 2014. Hubungan Pendidikan, Masa Kerja dan Beban Kerja dengan Keselamatan Pasien RSUD Haji Makassar. Manajemen RS FKM UNHAS. $1(1): 1-8$

Depkes RI. 2011. Panduan Nasional Keselamatan Pasien Rumah Sakit. Jakarta: Depkes RI

Fadriyanti, Y., Yosi S. 2018. Hubungan Jam Kerja dan Karakteristik Perawat Pelaksana dengan Penerapan Sasaran Keselamatan Pasien pada Rumah Sakit di Kota Padang. Menara Ilmu 12(6): 170-180

Handayani, M., Rini A., M Alimin M. 2014. Determinan Kepatuhan Perawat di Ruang Rawat Inap Stella Maris Makassar.Manajemen RS FKM UNHAS 1(1): 1-10

Kamil, H. 2011. Handover Dalam Pelayanan Keperawatan. Idea Nursing Journal. 2(3): 1-11

KKPRS. 2012. Pedoman Insiden Keselamatan Pasien Edisi 2. Jakarta: Depkes RI

Kozier et all. 2010. Buku Ajar Fundamental Keperawatan Konsep Proses dan Praktik. Jakarta: EGC 
Lestari. 2012. Kitab Undang-Undang Tentang Kesehatan dan Kedokteran. Yogyakarta: Bukubiru

Manopo, Quiteria, Frangky, R.R.M., Jehosua, S.V.S. 2013. Hubungan antara penerapan Timbang Terima Pasien dengan Keselamatan Pasien oleh Perawat Pelaksana di RSU GMIM Kalooran Amurang: Manado Sulawesi Utara. Master's Thesis. 1(2): 1-8

Manorek, H,. A. Joy M.R., Tubagus D.E.A. 2017. Faktor-Faktor yang Berhubungan dengan Penerapan Sasaran Keselamatan Pasien Pada Perawat di R. Rawat Inap RSUD Sam Ratulangi Tandano. Ikmas. 2(4): 65-76

Notoatmodjo, S. 2012. Promosi Kesehatan dan Perilaku Kesehatan. Jakarta: Rineka Cipta

Nursalam. 2011. Manajemen Keperawatan Aplikasi dalam Praktik Keperawatan Profesional Edisi 3. Jakarta : Salemba Medika

Pegala, I., Zahroh S., Baju W. 2017. Perilaku Kepatuhan Perawat Melaksanakan SOP Terhadap Kejadian Keselamatan Pasien di Rumah Sakit X Kendari. Jurnal Promosi Kesehatan Indonesia. 12(1): 138-149

Permenkes. 2017. Peraturan Menteri Kesehatan Republik Indonesia nomor 11. Jakarta: Depkes RI

Potter, P.A dan Perry, A.G. 2010. Buku Ajar Fundamental Keperawatan: Konsep Proses dan Praktikum Edisi Ketujuh Buku Ketiga. Jakarta: EGC

Putri, Z. M., Hanny H., Efy A. 2016. Karakteristik Perawat dan Perilaku Keselamatan Kerja Perwat di RSUD Depok. Ners Jurnal Keperawatan. 12(1): 67-75

Qomariah, S.N. dan Uyan A.L. 2015. Hubungan Faktor Komunikasi dengan Insiden Keselamatan Pasien. Journals of Ners Community . 6(2): 1-7

Rosyada, S.D. 2014. Gambaran Budaya Keselamatan Pasien Pada Perawat Unit Rawat Inap Kelas III Rumah Sakit Umum Daerah Pasar Rebo Bulan Juni Tahun 2014. [Skripsi]. Jakarta (ID): Univesitas Islam Negeri Syarif Hidayatullah Jakarta

Sugiharto, A.S,Keliat,A.B dan Sri, H.T. 2012. Manajemen Keperawatan: Aplikasi MPKP di Rumah Sakit. Jakarta: EGC

Sugiyono. 2011. Metode Penelitian Kuantitatif, Kualitatif dan R\&D. Bandung: Alfabeta

Suhriana. 2012. Faktor yang Berhubungan dengan Kinerja Perawat di Unit Rawat Inap RSUD Bula Kabupaten Serang Bagian Timur. [Skripsi]. Makassar (ID): UNHAS

Triwibowo, Cecep. 2013. Manajemen Pelayanan Keperawatan di Rumah Sakit. Jakarta: CV Trans Info Media

Triwibowo, C., Zainuddin H., Soep. 2015. Studi Kualitatif: Peran Handover dalam Meningkatkan Keselamatan Pasien di Rumah Sakit. Pena Medika Jurnal Kesehatan. 6(2): $72-79$

WHO. 2017. Patient Safety. apps.who.int/iris/bitstream/10665/255507/1/WHO-HIS-SDS2017.11-eng.pdf diakses pada tanggal 30 Januari 2018 